\title{
Fintech: A Literature Review
}

\author{
Ferdinando Giglio ${ }^{1}$ \\ ${ }^{1}$ Department of Economics, University of Campania "Luigi Vanvitelli", Capua, Italy \\ Correspondence: Ferdinando Giglio, PhD at University of Campania "Luigi Vanvitelli", Corso Gran Priorato di \\ Malta, 1, Capua 81043, Italy.
}

Received: November 26, 2021

Accepted: December 13, $2021 \quad$ Online Published: December 17, 2021

doi:10.5539/ibr.v15n1p80

URL: https://doi.org/10.5539/ibr.v15n1p80

\begin{abstract}
This article analyzes the Fintech evolution. After describing the process of this phenomenon, some of the main definitions are provided both nationally and internationally. Finally, six main models of Fintech are analyzed.

Through a systematic literature, 14 articles have been selected that deal with the phenomenon of Fintech.

Six Fintech business models implemented by the ever growing number of Fintech startups have been identified, payment, wealth management, crowdfunding, loan, capital market and insurance services. Internationally, Fintech has already been defined by the International Monetary Fund (IMF), the World Bank Group (WBG), the Financial Stability Board (FSB), the Organization for Economic Cooperation and Development (OECD), the International Organization of Securities Commissions (IOSCO), the Bank for International Settlements (BIS). On a national level, on the other hand, Fintech has been analyzed by various countries, USA, United Kingdom, Singapore, China, Switzerland, China, Australia and the European Union.

Fintech refers to a broad set of innovations - observable in the financial field in a broad sense - which are made possible by the use of new technologies both in the offer of services to end users and in the internal production processes of financial operators as well as in the design of market enterprises, without thereby compromising new possible configurations of intersectoral activities.

Fintech appears to be representative of innovative methods - based on technology - of carrying out activities directly or indirectly connected to financial services rather than being a pre-defined industrial sector. Following the logic of the digital economy, Fintech contributes to designing an open and continuous network of modular services for businesses, individuals and banking, financial and insurance intermediaries, becoming a powerful acceleration force for the integration policies of the financial services markets in the EU.
\end{abstract}

Keywords: fintech

\section{Introduction}

E-government, e-governance and information systems were born thanks to the advent of the world wide web (Razzaque and Karolak, 2010). Concepts such as knowledge management have received great consideration in both corporate and managerial research (Razzaque and Hamdan, 2020). The financial sector also contributed predominantly to the emergence of these information systems.

It is claimed that a new era of Fintech is dawning; this phenomenon embraces various sectors such as: financial, technological and innovative. The word Fintech arises from the union of two terms, such as: finance and technology. Fintech describes the relationship of various technologies with financial assets.

This phenomenon has been the subject of research by many researchers who have outlined its history and evolution. The document is structured as follows: after having illustrated the evolution of Fintech, some of the main definitions of this term are provided at national and international level and finally the main models of this phenomenon are examined.

\section{Fintech 1.0 (1866-1967): Towards the Digital World}

The terms "finance" and "technology" have been linked to each other. Finance was born through administrative systems (Rowlinson, 2010).

According to Mervyn King (2003-2013): "The story of money is... the story of how we evolved as social animals, trading among ourselves. It begins with the use of commodities such as money, grain and livestock in 
Egypt and Mesopotamia as early as 9000 BC. ... The cost and inconvenience of using such commodities have led to the emergence of precious metals as the dominant form of money. Metals were first used in transactions in ancient Mesopotamia and Egypt, with metal coins originating in China and the Middle East and remained in use until the 4th century BC. The first banknotes appeared in China in the 7th century AD. "(King, 2016).

Banknote represents a technology that illustrates alienable values (McGroarty, 2011); this is a feature of the modern economy. In addition, the birth of the first information technologies has supported financial transactions. Another form of information technology is double-entry accounting (Spoke, 2015) which was born from the union of finance and commerce in the medieval period.

In this period, the advancement of technology has been helped by finance and access to capital. For this reason, the link between finance and technology is long-standing, with a journey that lays the foundations for the modern era.

\subsection{The First Period of Financial Integration}

Finance and technology came together to give life to what has been called the first period of financial globalization. Financial interconnections have been supported by various technologies such as telegraphs, railways, canals and steamships and have enabled the transmission of financial information in the world. At the same time, resources have been provided by the financial sector to make these technologies effective (Roth and Dinhobl, 2008).

\subsection{The Early Post-War Period}

Even after the First World War, technological tools continued to develop. Texas Instruments, in fact, created the first financial calculator in 1967 (Thibodeau, 2007). The first fax dates back to 1964 thanks to Xerox Corporation (Auth, 2016).

\section{Fintech 2.0 (1967-2008): Traditional Digital Financial Performances}

Fintech 2.0 is natp thanks to the birth of the ATM. The second period of Fintech runs from 1967 to 1987.

\subsection{Digitalization and Globalization of Finance}

In the late 1970s, electronic payment systems changed rapidly. The Inter Bureau was born in the United Kingdom in 1968, establishing the base of the Bankers' Automated Clearing Services, (Welch, 1999) while the Interbank Payments System in 1970 (Federal Reserve Bank of New York, 2002). Fedwire became an electronic system in the early 1970s (Federal Reserve Bank of N.Y., 2015). The BIS Payments and Settlements Committee was established in 1990. In the securities industry, the transition from trading physical securities from the late 1600s to the present was due to the establishment of the National Association of Securities Dealers Automated Quotations in the United States in 1971. Online banking was introduced in the United States in 1980 and in the United Kingdom in 1983 (Choron and Choron, 2011). Also in that year there was "Black Monday". All this has led regulators to work on mechanisms to foster cooperation on cross-border securities markets (Steinberg, 1999). The Single European Act, the 1992 Maastricht Treaty and various directives and regulations on financial services, have laid the foundations for full interconnection.

\subsection{What Are the Regulatory Approaches in Fintech 2.0?}

Due to the change in technology, the regulatory framework and strategies have also changed. Great efforts have been made in the United States and Europe. Regulating new innovations applicable to the financial sector has a limited advantage (Chan, 2016). Internet banking could eliminate the numerous lines at the branches, allowing customers there operations directly from home (Carse, 2016). By eliminating the physical link between customer and bank, competition was expected to increase. Internet banking has advantages, most notably better data organization which leads to an understanding of the real credit risk of borrowers (Douglas Arrier and Jarios Barberis, 2015). The distinction between risk and Fintech stratup marks the transition to Fintech 3.0.

\section{Fintech from 2008 to the Present Day}

The global financial crisis of 2008 is a turning point and may have fostered the growth of the Fintech 3.0 era. Indeed, since 2008, the image of the brand and the perceived stability of banks have been compromised.

Research from 2015 found that bank confidence levels are affected by Americans' abilities in tech companies. China is an example of this phenomenon (Weihuan Zhou, Douglas W. Arner and Ross P. Buckley, 2015) with over 2,000 P2P lending platforms operating outside a specific regulatory framework (Alois, 2015).

This does not demoralize millions of lenders and borrowers, who are willing to lend or borrow billions on these platforms due to the lower cost, seemingly better potential return, and greater affordability. There may be a lack 
of "legacy behavior" in developing markets so that the public does not expect only banks to provide financial services. As effectively described more than two decades ago, "banking is necessary, banks are not" (McLean, 1998).

\subsection{Can Fintech Be Called a Revolution?}

The bank and customers have been hit hard by the financial crisis. First, the public perception of banks has deteriorated (Sumit Agarwal et al., 2014). Second, the crisis has affected two groups of people (Kell, 2014). Many finance professionals have discovered FinTech 3.0 in which to put their skills into practice (Mark Esposito and Terence Tse, 2014).

The training of recent graduates has provided the tools to understand the financial markets and their skills have found a favorable outlet in Fintech 3.0. Post-financial crisis regulation has increased banks' correspondence obligations and changed corporate structures. The universal banking model presents obligations and capital increases. In this way, the way in which banks grant loans changes (Ferrari, 2016). The crisis was also caused by the not always appropriate way of using financial instruments (Segoviano et al., 2013). Finally, schemes have been put in place to prevent bank failure. In fact, these latest ones required recovery plans and stress tests were put in place to assess their concreteness (Barberis, 2012).

\subsection{The Birth of Fintech 3.0}

Post-crisis reforms have had the effect of stimulating the rise of new technology players (Release, 2013). This has led to disadvantages, including the embezzlement of capital. For this reason, consumers have relied on P2P lending platforms. The request for greater access to credit was granted thanks to the Jump Start Our Business Startups (JOBS).

\subsection{How Is the Fintech Industry Made?}

Fintech comprises 5 domains: (1) finance and investments, (2) internal operations and risk management, (3) payments and infrastructure, (4) data security and monetization, and (5) customer interface.

In the first group, many investors focus on financing mechanisms, such as P2P lending.

Internal financial transactions and risk management represent the second fundamental area of Fintech for financial institutions because they have created the best compliance systems to cope with the changes that have taken place after the crisis (Marino, 2015).

Payments and infrastructures have represented the development of national electronic payment systems.

The security and monetization of data have allowed consumers to be more protected when carrying out a financial transaction.

Finally, the interface will continue to be an essential point of traditional financial services.

\section{Definitions of Fintech}

Fintech was born thanks to the invention of Citicorp with a precise project. Over time, this phenomenon has intrigued the public. Imran (2014) found that Fintech has been used in the service sector. It proposes a change especially in the banking services sector (Imran, 2019). There is a great variety of definitions of the term in academic practice and business journals. Table 1 shows some of the main definitions of the term Fintech.

Table 1. Definitions of Fintech

\begin{tabular}{|l|l|l|}
\hline Definitions & Source & Year \\
\hline $\begin{array}{l}\text { Fintech not only encompasses specific sectors but also covers a whole } \\
\text { range of financial services and products. }\end{array}$ & $\begin{array}{l}\text { Arner, DW; Barberis, JN; } \\
\text { Buckley, RP }\end{array}$ & 2015 \\
\hline $\begin{array}{l}\text { The creation and dissemination of new financial instruments describe } \\
\text { financial innovation. }\end{array}$ & Farha Hussain & 2015 \\
\hline $\begin{array}{l}\text { Fintech is defined as an industry made up of many companies that make } \\
\text { financial systems more efficient. }\end{array}$ & McAuley, D. & 2015 \\
\hline $\begin{array}{l}\text { Fintech uses IT technology to improve the efficiency of the financial } \\
\text { system. }\end{array}$ & $\begin{array}{l}\text { Kim, Y., Park, Y. J., \& } \\
\text { Choi, J. }\end{array}$ & 2016 \\
\hline Fintech describes a financial services industry born in the 21st century. & Investopedia & 2016 \\
\hline $\begin{array}{l}\text { Fintech makes use of modern software and technologies. } \\
\text { Fintech combines different business models to make the financial system weekly } \\
\text { better. }\end{array}$ & Ernst \& Young & 2016 \\
\hline
\end{tabular}




\section{The International Definitions of Fintech}

Some of the definitions of the term Fintech internationally have been reported.

The BFA describes Fintech as a technological advance capable of innovating the provision of financial services (IMF, 2018).

Instead, the FSB defines it as a technology that has contributed not only to innovation in the financial sector but also to the emergence of new business models (FSB, 2019).

The OECD, on the other hand, defines Fintech as the innovative application of digital technology for financial services (OECD, 2018).

IOSCO states that Fintech is a variety of innovative business models with the potential to transform the financial services sector (IOSCO, 2017).

Finally, the Basel Committee defines Fintech as a company whose main task is to provide innovative services, such as the launch of new technologies in the financial sector.

\section{Definitions of Fintech at the National Level}

\subsection{Fintech in USA}

In the United States, there is no clear-cut framework for fintechs. Fintech is defined by the National Economic Council as a set of innovations in financial assets (National Economic Council, 2017).

The first sandbox was born in Arizona that allowed entrepreneurs and companies to have their own products and services (State of Arizona, 2018).

\subsection{Fintech in the United Kingdom}

Even in the UK, as in the US, there is no regulation for fintechs. The guidelines are provided by the Financial Conduct Authority which argues that innovation has good potential to make customers' lives better. For this reason, the FCA has given life to the "2 innovate" project with the aim of promoting innovation even more.

\subsection{Fintech in Singapore}

In Singapore, there is a balance between rules and Fintech. The latter are institutions administered by the Monetary Authority. Under the MAS, applications can be submitted by two entities: a financial institution licensed as a partner and one licensed in the capital sector (MAS, 2019a).

\subsection{Fintech in China}

In China, Fintechs allow you to pay, lend and sell online. For this reason, they help e-commerce companies to sell and distribute financial products.

\subsection{Fintech in Australia}

In Australia, fintechs spread innovation when they allow markets and financial systems to be effective and consumer-oriented (The Australian Government, 2016).

\subsection{Fintech in Switzerland}

In Switzerland, Fintechs are based on the principle of technological neutrality and are regulated by the Federal Supervisory Authority. A requirement that Fintechs in Switzerland must have is the fact that they must be joint-stock or limited liability companies or that they must have their registered office in Switzerland (FINMA, 2018).

\subsection{Fintech in The European Union}

The European Union has lagged behind the United States and China. Fintechs are described as lenders enabled through new technologies to create innovation (European Parliament, 2017).

\section{Business Models of Fintech}

Six Fintech business models have been identified from the recent Accenture report (2016a): payments, wealth management, crowdfunding, lending, capital market and insurance services.

\subsection{Payment}

Fintech companies that focus on payments are able to acquire customers at low cost and are among the fastest in terms of switching and choosing new payment features. There are two types of market for payments: consumer and retail payments and wholesale payments. Consumer and retail payment fintechs include mobile wallets, peer-to-peer mobile payments, foreign currency, real-time payments, and digital currency settlement; wholesale 
transactions mainly deal with interbank transactions - such as money market contracts and foreign exchange transactions - as well as commercial payments, generally of a significant amount for which timely execution is required (Mellon, 2015).

\subsection{Wealth Management}

One of the wealth management fintech business models are wealth managers who use algorithms to suggest assets to invest in based on the client's needs (Ask the Algorithm, 2015). This model benefits from changing demographics and client attitudes that support automated investment strategies (Holland Fintech, 2015).

\subsection{Crowdfunding}

Crowdfunding fintechs allow people to verify the creation of new products and media (International Trade Administration, 2015). Crowdfunding has three parts: the promoter of the project, the contributors who may be interested in supporting the cause or project and the founder.

Three typologies of crowdfunding are: based on rewards, donations and shares.

Reward-focused crowdfunding has been an interesting fundraising choice for thousands of small businesses and innovative projects.In the event that there is interest to be charged on the premium-based crowdfunding amount, the borrower sets the interest rate at which feels comfortable and can guarantee reimbursement within the established time period (Mollick, 2014). Donation-based crowdfunding is a way to raise money for a charity project by asking donors to participate with money. In a donation-based crowdfunding, the lender receives a form of non-monetary reward. Share-based crowdfunding is an attractive option for small and medium-sized businesses as the higher capital ratio requirements for traditional banks describe loans to SMEs as less needed than traditional banks. Share-based crowdfunding allows entrepreneurs to reach investors interested in having shares in their startup or other small private business.

\subsection{Lending}

P2P fintechs allow people to lend and borrow. They are able to guarantee lower rates and a better loan process for lenders and borrowers. P2Ps have no obligation to comply with capital requirements affecting total availability because they are not used in the loan itself (Williams-Grut, 2016).

\subsection{Capital Market}

Investors through trading fintechs can discuss with each other but above all they allow them to share knowledge, execute orders to buy and sell commodities and risk management. Trading fintechs allow the reduction of barriers and costs for SMEs transacting in foreign currencies around the world.

\subsection{Insurance Services}

A direct relationship between the customer and the insurer takes place in insurance-type fintechs. They employ data analytics to quantify and manage risk, and products are provided to customers to satisfy them. They facilitate healthcare billing processes.

\section{Conclusions}

This article wanted to highlight the evolutionary path of Fintech that culminated with Fintech 3.0 in 2008 wanted by several customers. After having dealt with this topic, some of the main definitions of the term Fintech have been provided both nationally and internationally. Finally, six Fintech models were analyzed, among them: payment, asset management, crowdfunding, lending, the capital market and insurance services.

\section{References}

Agarwal, S., \& Zhang, J. (2020). FinTech, Lending and Payment Innovation: A Review. Asia- Pacific Journal of Financial Studies, 49(7), 353-367. https://doi.org/10.1111/ajfs.12294

Arner, D., Buckley, R., \& Barberis, J. (2016). The Evolution of Fintech: A New Post-Crisis Paradigm? SSRN Electronic Journal, 47(4), 1271-1319. https://doi.org/10.2139/ssrn.2676553

Bollaert, H., Lopez-de-Silanes, F., \& Schwienbacher, A. (2021). Fintech and access to finance. Journal of Corporate Finance, 68(2), 1-14. https://doi.org/10.1016/j.jcorpfin.2021.101941

Goldstein, I., Jiang, W., \& Andrew Karolyi, G. (2019). To FinTech and Beyond. Review of Financial Studies, 32(5), 1647-1661. https://doi.org/10.1093/rfs/hhz025

Haitian, L., Bingzhong, W., Qing, W., \& Jing, Y. (2020). Fintech and the Future of Financial Service: A Literature Review and Research Agenda. China Accounting and Finance Review, 22(3), 107-136. 
Hasan, R., Kabir Hassan, M., \& Aliyu, S. (2020). Fintech and Islamic Finance: Literature Review and Research Agenda. International Journal of Islamic Economics and Finance, 1(2), 75-94. https://doi.org/10.18196/ijief.2122

Keke, G., Meikang, Q., \& Xiaotong, S. (2018). A survey on FinTech. Journal of Network and Computer Applications, 103, 262-273. https://doi.org/10.1016/j.jnca.2017.10.011

Lee, I., \& Jae Shin, Y. (2018). Fintech: Ecosystem, business models, investment decisions, and challenges. Business Horizons, 61(1), 35-46. https://doi.org/10.1016/j.bushor.2017.09.003

Mohamed, H., Hamdan, A., Karolak, M., Razzaque, A., \& Alareeni, B. (2021). FinTech in Bahrain: The Role of FinTech in Empowering Women. In book: The Importance of New Technologies and Entrepreneurship in Business Development: In The Context of Economic Diversity in Developing Countries. https://doi.org/10.1007/978-3-030-69221-6_57

Puschmann, T. (2017). Fintech. Bus Inf Syst Eng, 59(1), 69-76. https://doi.org/10.1007/s12599-017-0464-6

Randy Suryono, R., Budi, I., \& Purwandari, B. (2020). Challenges and Trends of Financial Technology (Fintech): A Systematic Literature Review. Information, 11(12), 1-20. https://doi.org/10.3390/info11120590

Rupeika-Apoga, R., \& Thalassinos, E. (2020). Ideas for a Regulatory Definition of FinTech. International Journal of Economics and Business Administration, 8(2), 136-154. https://doi.org/10.35808/ijeba/448

Schueffel, P. (2016). Taming the Beast: A Scientific Definition of Fintech. Journal of Innovation Management, 4(4), 32-54. https://doi.org/10.24840/2183-0606_004.004_0004

Varga, D. (2017). Fintech, the new era of financial services. Budapest Management Review, 48(11), 22-32. https://doi.org/10.14267/VEZTUD.2017.11.03

\section{Copyrights}

Copyright for this article is retained by the author(s), with first publication rights granted to the journal.

This is an open-access article distributed under the terms and conditions of the Creative Commons Attribution license (http://creativecommons.org/licenses/by/4.0/). 